\title{
Modeling the Marvel Everyfan: Agent Coulson and/as Transmedia Fan Culture
}

\section{Suzanne Scott ${ }^{1}$}

Recibido: 2017-02-28

Enviado a pares: 2017-03-01
Aprobado por pares: 2017-05-15

Aceptado: 2017-06-01

DOI: 10.5294/pacla.2017.20.4.8

Para citar este artículo / to reference this article / para citar este artigo

Scott, S. (2017). Modeling the Marvel everyfan: Agent Coulson and/as transmedia fan culture. Palabra Clave, 20(4), 1042-1072. DOI: 10.5294/pacla.2017.20.4.8

\section{Abstract}

This article contends that the transmedia franchising model pioneered by the Marvel Cinematic Universe (MCU) has worked to structurally produce an industry-approved conception of an everyfan. This transmedia everyfan, modeled as an avid consumer, collector and completist, importantly privileges stereotypically male-dominated modes of fan engagement, and works to contain or circumvent the transformative textual work performed predominantly by female fans. Though a close (para)textual analysis, this article uses the character of S.H.I.E.L.D Agent Phil Coulson as an allegorical lens to consider how transmedia fan participation is constructed, valued, and gendered in our current franchise-heavy mediascape.

\section{Keywords}

Transmedia; fandom; franchising; gender; Marvel (Source: Unesco Thesaurus).

1 The University of Texas at Austin, United States. suzanne.scott@utexas.edu 


\section{Modelando el everyfan de Marvel: agente Coulson y/como cultura de los fans transmedia}

\section{Resumen}

Este artículo sostiene que el modelo de franquicia transmedia, del que el Universo Cinematográfico de Marvel (MCU) es pionero, ha trabajado para producir estructuralmente una concepción aprobada por la industria del everyfan. Esta transmedia del everyfan, modelado como un ávido consumidor, coleccionista y complementista, privilegia los modos estereotipados de dominación masculina de la participación de los fans y trabaja para contener o eludir el trabajo textual transformador realizado predominantemente por las fans. A pesar de ser un análisis (para)textual cercano, este artículo utiliza al personaje del agente de S.H.I.E.L.D, Phil Coulson, como una lente alegórica para considerar cómo se construye, valora y genera la participación del fan transmedia en nuestro paisaje mediático de franquicia.

\section{Palabras clave}

Transmedia; fandom; franquicia; género; Marvel (Fuente: Tesauro de la Unesco). 


\section{Modelando o everyfan de Marvel: agente Coulson e/como cultura de fã transmídia}

\section{Resumo}

Este artigo reafirma que o modelo de franquia transmídia, do qual o Universo Cinematográfico de Marvel (MCU) é pioneiro, tem trabalhado para produzir estruturalmente uma concepção aprovada pela indústria do everyfan. Esta transmídia doeveryfan, modelado como um ávido consumidor, colecionista e de complemento, privilegia os modos estereotipados de dominação masculina da participação dos fãs e trabalha para conter ou eludir o trabalho textual transformador realizado predominantemente pelas fãs. Apesar de ser uma análise (para) textual próxima, este artigo utiliza o personagem do agente de S.H.I.E.L.D, Phil Coulson, como uma lente alegórica para considerar como se constrói, avalia e gera a participação do fã transmídia em nossa paisagem mediática de franquia.

\section{Palavras-chave}

Transmídia; fandom; franquia; gênero; Marvel (Fonte: Tesauro da Unesco). 
Superheroes have long served as the foundation for transmedia stories, leaping from the pages of comic books and pulp magazines to radio and film serials as early as the 1930s, and more recently evolving into the dominant franchising model in an era of horizontally integrated media conglomerates. The Marvel Cinematic Universe (hereafter MCU) might be cited as prime evidence that we have reached peak fan-centric transmedia planning. Currently spanning nearly a decade, fourteen films, two network television series and five streaming series, and an array of tie-in comic books and short films, the MCU did not invent the concept of transmedia franchising, but it has undeniably popularized it and proved the most prolific and profitable textual example of it. This article considers the symbolic significance of one character in this vast universe, S.H.I.E.L.D. Agent Phil Coulson (played by Clark Gregg). S.H.I.E.L.D. has a storied history within Marvel Comics dating back to the spy agency's first appearance in Stan Lee and Jack Kirby's (1965) Strange Tales \#135. However, the first phase of the MCU predominantly used S.H.I.E.L.D. and Coulson as its primary agent in every sense of the word, as a transmedia planning device to collect and ultimately bring together The Avengers (2012) titular superhero team.

Specifically, this article contends that Coulson, as one of the rare original characters in Marvel's vast transmedia franchise, serves a pedagogical purpose designed to diegetically function as both a de facto transmedia producer as well as a desired MCU everyfan. Introduced in Iron Man (Arad, Feige, \& Favreau, 2008), the MCU's inaugural film, Coulson is notably the only character to appear across all of the transmedia franchise's canonical delivery channels: film, television, short films, and comics. This is fitting, because Coulson is the fictive glue that initially bound the MCU together, moving from text to text, collecting superheroes along the way. But this narrative functionality is not the only way in which we might read Coulson as an agent of the MCU in addition to S.H.I.E.L.D. In doing the textual work of a transmedia producer for the MCU, Coulson also reflects desired modes of fan interaction and engagement. This attempt to model a consumer- and collector- oriented mode of transmedia fan engagement is further compounded by the reveal of Coulson as a (literal) card-carry- 
ing Captain America fanboy in The Avengers (Feige \& Whedon, 2012). In a transmedia franchise built off of pre-existing superhero intellectual property, Coulson is a highly relatable everyman character designed to model everyfan behaviors.

This project centrally responds to Carlos Scolari's (2009) work, which calls for more research on how the implicit (or presumed) consumers of transmedia stories are constructed and conveyed through narratological and semiotic analysis. Just as Scolari adapts Umberto Eco's (1979) claim that texts "give explicit information about the sort of readers they presuppose" (p. 7), thereby suggesting an implied reader, this article further draws on Eco's theory of Model Readers to suggest that transmedia franchises, which are by definition "well-organized" textual networks, presumed "a model of competence coming $[\ldots]$ from outside the text," even as they simultaneously endeavor "to build up, by merely textual means, such a competence" (Eco, 1979, p. 8). The following textual analysis positions Coulson as the MCU's model reader, further suggesting that Coulson's primary narratological function is to model transmedia consumption that builds up and diegetically rewards forms of fan engagement that are most beneficial (or least threatening) to media industries.

Though the textual corpus for this project included all of Coulson's appearances in films, comics, television series, and video games, this article focuses on Coulson's canonical appearances within the MCU. This includes four of the six films that comprise Phase One of the MCU's transmedia franchise (2008's Iron Man, 2010's Iron Man 2, 2011's Thor, and 2012's The Avengers), as well as a series of Marvel One-Shots, which are short films released as supplementary DVD content. The ABC television series Agents of S.H.I.E.L.D. (Loeb, 2013) and Marvel Comics' series of the same name (Guggenheim \& Peralta, 2016), in which Coulson is the protagonist, are addressed briefly. I also consider the semiotic significance of both promotional and fan-created paratexts featuring Coulson, ranging from marketing materials (movie posters, interviews, articles, etc.) to transformative works (fanfiction, fan art, etc.). In doing so, this project expands on existing schol- 
arship considering how transmedia tie-ins and paratexts function as a form of brand fanagement (Hills, 2012), suggesting "correct" or "desired" readings (see Gray, 2010 and Kompare, 2011).

Through this close (para)textual analysis, this article will contend that the franchising model pioneered by Marvel and Disney via the MCU has worked to structurally produce an industry-approved conception of a transmedia everyfan. The transmedia everyfan is modeled as an avid canonical consumer, collector, and completist. Building on my prior work (Scott, $2010,2012,2013 a$ ) addressing the tightly constrained and often pointedly gendered modes of fan engagement courted by transmedia stories, this article uses the character of Agent Coulson as an allegorical lens to consider how fan participation and production is constructed and valued in our current transmedia franchise-heavy mediascape. The representational reveal of Coulson's own fan identity, and his subsequent death in The Avengers and rebirth via a combination of fan activism and franchising logics, offers a rich site to explore tensions surrounding conceptions of participation within transmedia fan culture. Finally, I will briefly examine transformative fan works to consider how audience segments marginalized by this construction of the MCU everyfan textually engage and/or disrupt Coulson's positioning within the franchise.

\section{Modeling Transmedia Franchising and Fandom in the MCU}

Before delving into how Coulson allegorically functions as a representational double agent (simultaneously embodying the roles of MCU transmedia producer and everyfan), it is vital to unpack how transmedia has conceptually migrated from the academy to industry over the past decade. Henry Jenkins (2006) popularized the term transmedia storytelling in a chapter of his book, Convergence Culture: Where Old and New Media Collide, focused on The Matrix franchise. Here, I utilize the definition provided by Jenkins in a 2007 blog post entitled "Transmedia Storytelling 101" because, as the pedagogical title suggests, it was designed to be the most widely accessible and applicable introduction to the term. Jenkins (2007) defines transmedia 
storytelling as "a process where integral elements of a fiction get dispersed systematically across multiple delivery channels for the purpose of creating a unified and coordinated entertainment experience" (para. 3). Though this definition seems to neatly describe the design and appeal of the MCU, with its interlocking superhero narratives and systemically designed production phases, its application requires further contextualization.

As the $C$ of the MCU suggests, this effort to build a highly coordinated and unified entertainment experience for fans, however successful, was initially (and remains overwhelmingly) medium specific. Exceptions in the form of tie-in limited run comic books and short films timed to capitalize on and promote new installments of the film franchise were in no way integral to an understanding of the MCU. In 2013, the MCU began to more actively span multiple delivery channels with coordinated content: first, with forays into television through two series at $\mathrm{ABC}$, a network owned by Marvel's parent company, Disney (Marvel's Agents of S.H.I.E.L.D. [2013present] and Marvel's Agent Carter [2015-2016]), and later with an array of Netflix streaming television series (Marvel's Daredevil [2015-present], Marvel's Jessica Jones [2015-present], Marvel's Luke Cage [2016-present], and Marvel's Iron Fist [2017-present]). The Netflix shows structurally replicate film franchise's transmedia strategy, building from series focused on one character to a superhero team crossover event, 2017's Marvel's The Defenders. Though narrative references to the cinematic universe are occasionally deployed in these various television and streaming series to enrich their connection to the MCU for fans, on the whole, these series do not textually impact the films. Thus, under a stringent reading of Jenkins' definition, the MCU presents a textually fraught transmedia test case.

Jenkins' (2007) post openly acknowledges the appeal of the term transmedia to media creators and the horizontally integrated industries they produce within, noting that transmedia storytelling "reflects the economics of media consolidation or what industry observers call 'synergy." (para. 4). Responding to the industry's enthusiastic adaption and adaptation of the term, Jenkins (2007) is careful to stress narrative complexity and world building, as well as audience agency, as cornerstones of transmedia story- 
telling. We can also perhaps read Jenkins' definitional post as a response to the growing dilution of the term: For every instance of a media company experimenting with the narrative tenets of transmedia storytelling, there were dozens deploying the buzzword to simply rebrand synergistic strategies with a more interactive and fan-focused label.

In this sense, the industrial embrace of transmedia storytelling, generally, and Marvel's conception of the MCU as a transmedia franchise, specifically, has hewed closer to another originating definition of transmedia. In her book Playing with Power in Movies, Television, and Video Games: From Muppet Babies to Teenage Mutant Ninja Turtles, Marsha Kinder (1991) introduced the terms transmedia intertextuality and commercial transmedia supersystems to describe how franchises functioned as an industrial survival strategy in an era of corporate mergers. Kinder was markedly less enthusiastic about this mode of cross-platform storytelling, arguing that, though transmedia supersystems promise more diversity and interactivity, they ultimately instill a false sense of power and choice in the audience while disavowing any commercial manipulation. If Jenkins' definition acknowledged the industrial incentives for embracing transmedia, but ultimately chose to focus on the form's storytelling benefits for creators and consumers, Kinder's initial conception of transmedia supersystems focused on how the narrative form's proliferation of commodities and emphasis on consumption serves the interests of media conglomerates.

That the MCU could easily be aligned with either of these foundational definitions of transmedia is perhaps central to its broad appeal as a franchising model to media industries and audiences alike. In their respective studies of Marvel Studio's “aggressive self-understanding” (Connor, 2012, p. 527) and how that understanding was conveyed in self-reflexive trade stories prior to Disney's acquisition of Marvel in 2009 (Johnson, 2012), J. D. Connor and Derek Johnson both suggest that a similar paradox was central to the company's (and, later, the MCU's) self-conception and promotion. Connor contends that the marketing campaign for The Incredible Hulk (Arad, Hurd, Feige, \& Leterrier, 2008) perfectly embodied Marvel Studio's "two-sidedness; it suggested deep reserves of independent author- 
ship beneath its 'popcorn' façade" (Connor, 2012, p. 529). Similarly, Johnson (2012) frames Marvel Studios as walking a discursive, ideological and organizational tightrope, balancing age-old synergistic storytelling strategies with a reimagination of creative coordination and restructuring of production cultures. In part because the Marvel Model and the contemporary understanding of transmedia franchising have become so conceptually intertwined, it is important to note that the two-sidedness endemic to Marvel Studio's self-branding (independent/blockbuster; old/new storytelling and business models) also extends to transmedia franchising logics.

Jenkins (2007) himself openly acknowledges this, noting that the "current configuration of the entertainment industry makes transmedia expansion an economic imperative," while still emphasizing that transmedia creators can "surf these marketplace pressures to create a more expansive and immersive story" (para. 4). I have argued elsewhere that this surfing is markedly more complex for pre-existing fan communities of practice (Scott, 2010). Female fans, who are more historically predisposed to performing their own expansions of a storyworld, might be particularly wary of this inherent two-sidedness, resulting in tension "between those who claim that transmedia storytelling systems offer fans sophisticated webs of content to explore and enhance and those that see these webs as precisely that: a mode of confining and regulating fannish analysis and textual production" (Scott, 2010, p. 30). Keeping this in mind, one important commonality between Kinder's and Jenkins' foundational conceptions of transmedia is that the narrative design encourages collectability via consumption as its primary mode of audience engagement and its central appeal for fans. Whereas Kinder focused predominantly on the tangible collection of merchandise and purchase of transmedia extensions, Jenkins' emphasized the collectible properties of transmedia narratives through the cultivation and curation of textual data.

Jason Mittell (2015) has subsequently suggested that a primary textual quality of complex or transmedia narratives is that they are drillable (p. 288), promoting a model of engagement that he calls forensic fandom, which encourages audience to become "amateur narratologists, noting pat- 
terns and violations of convention, chronicling chronologies, and highlighting both the inconsistencies and continuities" (Mittell, 2015, p. 52) across the text as a whole. Thus, it is simultaneously appropriate and ideologically significant that Jenkins (2003) abandoned Michel de Certeau's (1988) poaching metaphor in his discussion of fans' engagement with transmedia stories. Jenkins' (1992) early conceptions of media fans as "textual poachers” drew on De Certeau's (1988) framing of readers as textual travellers moving "across lands belonging to someone else, like nomads poaching their way across fields they did not write" (p. 174). When characterizing transmedia fans, Jenkins (2003) described them as "information hunters and gatherers, taking pleasure in tracking down character backgrounds and plot points and making connections between different texts within the same franchise" (para. 4). Though transmedia franchising is often credited with shifting fannish modes of engagement from the margins to the mainstream (thereby purportedly empowering fans), both transmedia franchising and this shift in terminology ultimately benefit an industry attempting to regulate participatory culture en masse. By framing the proposed pleasure for fans in transmedia stories as collection rather than co-optation or creativity, the industry encourages audiences and fans to work their fields, rather than moving on to cultivate their own land.

Transmedia stories' emphasis on collection or forensic fandom as their primary mode of fan participation thus raises a number of issues. First, this emphasis not only privileges historically masculine modes of fan engagement, it explicitly devalues any non-canonical modes of fan production or speculation. Thus, while both Kinder (1991) and Jenkins (2007) claim that transmedia systems and stories are designed to reach out to diverse audience segments, the analysis that follows suggests a desire to acknowledge and facilitate limited and demographically distinct modes of engagement. Though the conclusion of this article forcefully suggests that the transformative textual practices of predominantly female fans are in no way foreclosed by transmedia franchising logics, it is nonetheless significant that this narrative model valorizes and validates historically male-dominated fan practices, and in turn imagines male fans as the primary audience for its content. This gendered valuation of transmedia fan engagement is borne out in one of Mittell's (2009) earlier studies of forensic fandom, an examination of the 
fan wiki Lostpedia, for the ABC television series Lost (2004-2010). Mittell (2009) found that, precisely because of the television series' growing network of transmedia tie-ins and emphasis on information collection and canonical mastery, any fannish or non-canonical content, so-called "cruft," was deleted from pages on the fan wiki (e.g. the "Pairings" page went from documenting canonical couplings as well as fan ships ${ }^{2}$ to just the former). Though this content was ultimately restored on a page clearly marked fanon, Mittell notes that the incident was telling, as it functioned both as a "debate over how to appropriately use the site, as well as how best to watch the show itself” (para 2.11).

The linguistic significance of deeming feminized fannish content (character ships, slash ${ }^{3}$ pairings, etc.) cruft, a term that emerged within hypermasculine tech cultures to describe poorly designed or unnecessary code, quite literally "garbage" (Levy, 2010, p. 8), points to a gendered hierarchy of which modes of fan engagement, and indeed which fans, are valued within transmedia franchise fan cultures. Though Mittell (2009) builds on prior work on the gendered nature of fan wikis by Sarah Toton (2008), who suggests that the very process of collecting and cataloguing information on a fan wiki encourages the construction of boundaries (particularly around fan discussions of gender and sexuality), he suggests that the relationship between gender and mode of fan engagement is more complex. As the subsequent sections will explore, Agent Coulson offers a rich starting point to begin unpacking these tensions underpinning transmedia franchising, precisely because he is structurally and symbolically designed to function as a transmedia producer and everyfan of the MCU.

\section{Coulson as Transmedia Producer}

In a 2009 conversation with Sam Ford exploring how comic books' worldbuilding strategies prefigure many of the core tenets of transmedia franchising, Henry Jenkins notes, "From day one, one of the superhero's

2 Shipping, fannish shorthand for "relationshipping," refers to the fan practice of supporting or desiring a particular romantic pairing between characters that frequently remains unfulfilled within the media text.

3 Slash refers to the common fan practice of creating transformative works (fanfiction, fan art, etc.) exploring homoerotic relationships between characters that are not romantically coupled canonically. 
powers was to be able to leap across different media channels in a single bound" (p. 304). The irony within the MCU is that it is neither a superhero, nor a character originating in any of Marvel's comic books that most explicitly performs these feats, but rather an invented bureaucrat within a government agency. Whether or not this decision was intentionally made to offer fans interested in the MCU but unfamiliar with (or overwhelmed by) the tens of thousands of individual comics it draws its characters and narratives from a more "relatable" character to follow across cinematic channels is somewhat beside the point. While media industries and creators are centrally concerned with maintaining continuity when building transmedia franchises, stressing "absolute fidelity to one definitive version of a media franchise, fearing audience confusion," comics have historically embraced multiplicity, acknowledging that fans might "take great pleasure in encountering and comparing multiple versions of the same character" (Jenkins, as cited in Harrigan \& Wardrip-Fruin, 2009, p. 307).

Unlike Marvel Comics' approach, in which "multiplicity seems to coexist with continuity" (Jenkins, as cited in Harrigan \& Wardrip-Fruin, 2009, p. 307), the MCU has from the outset sold itself as a fan experience predicated on a deep valuation of continuity and connectivity. Considering that the Walt Disney Company's 2009 acquisition of Marvel for \$4 billion was driven by the desire to "identify properties that will help target an audience of younger boys more aggressively across multiple platforms" (Graser, 2009, n.p.), it is only fitting that Coulson was developed an original character for the MCU as a devoted "company man" in the Disney mode. In this section's conceptualization of Coulson as a transmedia producer, as well as the following section considering his symbolic representation as a desirable transmedia everyfan, it is thus important to note that Coulson in both character design and function is divorced from comics' logic of multiplicity, and firmly rooted in the continuity and continuous consumption logics of transmedia franchising.

By April 2010, transmedia storytelling had become prolific enough that the Producers Guild of America's Board of Directors approved the title of Transmedia Producer to their Code of Credits, defined as: 
the person(s) responsible for a significant portion of a project's longterm planning, development, production, and/or maintenance of narrative continuity across multiple platforms, and creation of original storylines for new platforms. Transmedia producers also create and implement interactive endeavors to unite the audience of the property with the canonical narrative and this element should be considered as valid qualification for credit as long as they are related directly to the narrative presentation of a project. (PGA, 2010, para. 5)

Exactly one month after this announcement, Iron Man 2 (Feige \& Favreau, 2010) was released and the MCU's first forays in utilizing Coulson as a crossover character began in earnest. As the analysis below will suggest, Coulson moves from supporting comic relief to de facto transmedia producer, functioning to maintain continuity across films in the franchise, develop storylines for new platforms (short film DVD content first, and eventually television and comic books), and unite the audience with the unfolding canonical narrative through his own fan identity.

After leaving on a mysterious mission to New Mexico mid-film, the post-credits scene of Iron Man 2 shows Coulson at the rim of a desert crater, reporting via phone that "We found it," as he gazes down at Thor's hammer Mjölnir. MCU post-credit scenes such as this one have become a cornerstone of the franchise's transmedia strategy, teasing new characters or fictional worlds that will be explored in forthcoming film installments in the franchise. In this sense, they function as migratory cues, a term coined by Marc Ruppel and deployed by transmedia scholar and practitioner Geoffrey Long to describe textual "hints in one media form to look for additional content in a different [transmedia] extension” (2007, p. 20). Notably, this Iron Man 2 post-credits scene was the first concrete migratory cue for fans of the MCU, teasing Thor's (Feige \& Branagh, 2011) cinematic release, as well as cementing Coulson's presence in the forthcoming film and his significance to the transmedia franchise.

Just as producers strategically build in migratory cues to direct fans to other points of consumption within a transmedia franchise, thereby attempting to keep fans focused on mapping textual connectivity or continuity, Coulson appeared in a series of Marvel One-Shots, short films that 
were included as DVD extras on an array of MCU films. "The Consultant," released on the Thor DVD, shows that is was Coulson who orchestrated the events depicted in the post-credits scene for The Incredible Hulk. Likewise, "A Funny Thing Happened on the Way to Thor's Hammer," released on the Captain America: The First Avenger (Johnston \& Feige, 2011) DVD, fills in the missing diegetic time between Coulson's departure in the middle of Iron Man 2 and his arrival in the film's post-credit scene.

Within the comic book industry and comics fan culture, a one-shot typically describes a stand-alone comic book issue that won't directly impact the unfolding narrative arc of a particular character or title. Similarly, these Marvel One-Shots featuring Coulson are positioned as amusing tangents or backstory - there are no moments of additive comprehension, no "new piece of information which forces us to revise our understanding of the fiction as a whole" (Jenkins, 2007, n.p.). Importantly, though, these Marvel One-Shots do clearly mark Coulson as the face of the MCU's transmedia storytelling endeavor, and position him as a narrative toehold for fans beginning to traverse multiple film texts and fictional universes. Longtime MCU producer Brad Winderbaum noted that the intended purpose of these One-Shots was to "paint a picture of S.H.I.E.L.D. pulling the strings and being responsible for some of the events we've seen in the films. What better character to represent this idea than Agent Coulson" (as cited in Julian, 2011, n.p.). In depicting Coulson as a sort of "puppetmaster," he is aligned with transmedia planning and production. The subsequent section's analysis of Coulson's appearance in The Avengers will explore how his producorial role, unifying individual character film franchises within the MCU transmedia franchise, evolves into a thematic exploration of Coulson's capacity to unify the superheroes around a common cause.

\section{Coulson as Transmedia Everyfan}

By the time the MCU's Phase One arrived at its cinematic climax with the superhero team-up, The Avengers (2012), Coulson was well-established as the binding transmedia force for the franchise, a fact that was reflected in his prominent placement in one of the film's promotional posters (Figure 1). Coulson's dominant promotional depiction, relegating Nick Fury 
(played by Samuel L. Jackson, inarguably the bigger star) to the background, speaks to both Coulson's popularity within the MCU fandom and his centrality to the franchise. Indeed, the entire plot of The Avengers hinges on Agent Coulson's murder by the film's villain, Loki (played by Tom Hiddleston). Before delving into the significance of Coulson's death and subsequent televisual rebirth via fan hashtag activism, it is necessary to address The Avengers' representation of Coulson as a Captain America/Steve Rogers (played by Chris Evans) fanboy. This plot point was teased as early as Iron Man 2, which featured a scene of Coulson discovering a prototype of Captain America's iconic shield (designed by Howard Stark in the MCU) and watching in horror as Tony Stark wedges it unceremoniously under an invention in order to make it perfectly level. While this scene functioned as a comedic "Easter Egg" for fans, The Avengers builds out Coulson's fanboy identity explicitly, juxtaposing his exchanges with Rogers with his prior interactions with superheroes like Iron Man (whom he treats as a fool who must be grudgingly suffered for the greater good) and Thor (who is approached as an object of intellectual curiosity more than affection).

\section{Figure 1. Promotional poster for The Avengers}

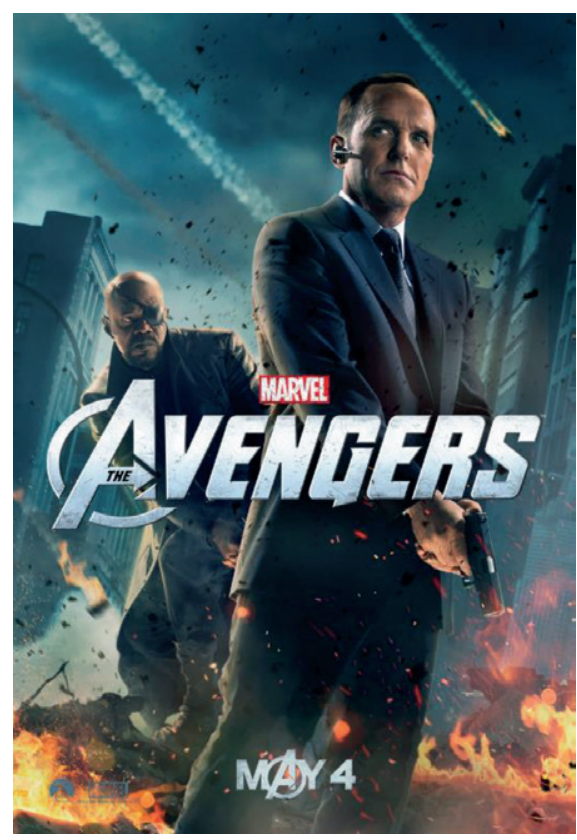

Source: Walt Disney Studios Motion Pictures. 
Coulson's first encounter with Rogers is played for laughs, with Coulson stammering his admiration for Captain America and admitting to watching him while he was "sleeping" (defrosting from the ice that had encased him since WWII), as Rogers averts his gaze, visibly uncomfortable. It would be easy to read this scene as diegetically disciplining "feminine" fan affect, with Coulson coded as harboring an infantilized "crush," presented as "too attached, too obsessed, and too invested" (Busse, 2013, p. 76) in his fan object. Indeed, as I have suggested above and elsewhere (Scott, 2012, 2013a), transmedia stories are designed to structurally support stereotypically masculinized modes of fan engagement such as the collection, critical analysis, and curation of narrative data and affiliated merchandise. In other words, the pleasures of transmedia stories, by design, lie in their canonical comprehension, and as a result might subtly discourage the types of creative intervention historically produced by female fans (such as fanfiction) as a valued mode of "participation." At the very least, Coulson's depiction as a fan suggests a narrow (not to mentioned decidedly analog) understanding of the myriad modes of fannish participation and affective engagement.

Vitally, then, it is not just that Coulson is represented as a fan in The Avengers, but as a particular type of fan: a collector. The fannish collector is an avid investor, both economically and emotionally, is reverent and detail-oriented, and above all a completist. As noted above, transmedia stories structurally encourage similar collective impulses and commitments of their fans, and transmedia franchises rely on these impulses to ensure continued consumption. Coulson's desire for Rogers to sign his set of vintage Captain America trading cards becomes a cornerstone of the film's plot, rendering even a throwaway line like "It took me a couple of years to collect them all. Near mint. Slight foxing around the edges," rich with meaning. Not only does this fannish depiction resonate deeply with Coulson's transmedial function over the course of the franchise as a "collector" of superheroes (indeed, it did take him exactly four years to "collect" the individual members of The Avengers from their respective film franchises), but his use of this particular jargon (mint, foxing) marks him specifically as a comics collector. 
It has been argued that comic book fan culture is commonly coded as an unilaterally male space, and accordingly "the comic book industry's failure to acknowledge the female audience is justified through economic rationalization," despite the fact that "anecdotal evidence suggests that the female readership for comics has been growing over the past decade, in part because of comics' integration into transmedia storytelling models" (Scott, $2013 \mathrm{~b}$, n.p.). One of the primary reasons this essentialist portrait of comic book readers has taken root is that comics collecting continues to be held up as the sine qua non of comics fandom, and the "most striking and expected demographic characteristic of the comic book collectors surveyed is that $100 \%$ are male" (Tankel \& Murphy, 1998, p. 60). Though both scholarly and industrial claims of this sort tend to be riddled with methodological issues in terms of both data collection and analysis (for example, Tankel and Murphy base this definitive claim on only 38 partially completed surveys across just two comic book shops), the faulty perception persists. On one level, privileging male comics collectors when conceptualizing comics fandom makes perfect sense, as collectors are most economically, temporally, and emotionally, committed, they are "invested" fans on multiple levels. As the MCU brings in a more demographically diverse audience, however, it has also endeavored to train these new fans via transmedia storytelling strategies to become collectors in their own right.

It is thus not a coincidence that Captain America is selected as Coulson's superhero fan object. Just as the longevity of transmedia franchises hinges on fan loyalty, Coulson's connection to his fan object is long held. Lincoln Geraghty (2014) has suggested that fan collection is driven by nostalgia, and Coulson's affect for Captain America is driven by a perceived purity of superheroes past. For example, after Coulson remarks that he has given input on the redesign of Captain America's costume, and Rogers retorts that the "stars and stripes" motif might be a bit too "old-fashioned," Coulson reassures him that in the midst of tumultuous times, "People might just need a little old-fashioned." Coulson's stoicism, his militaristic loyalty, and his moral certainty in his mission pointedly echoes Rogers' core character traits, and both are painted as everymen thrust into extraordinary circumstances. 
In conceptualizing Coulson as Marvel's transmedia everyfan, I would like to push this parallel further to suggest it is precisely the conservatism of Captain America that Coulson finds appealing, and is designed to valorize an equally conservative vision of transmedia fan culture. In other words, Coulson's representation reflects both a calculated and contained vision of the type of transmedia franchise fan that both Disney and Marvel have worked to inculcate. If "characters are a central, if not the central, point of engagement for the audience" (Evans, 2008, p. 203) within a transmedia story, then Coulson's place of prominence as the most actively transmediated character within the MCU functions as both the primary point and a model for audience engagement. Paul Booth (2015) notes that, as media representations of fans become more common, what has emerged are "twinned representations [that] implicitly contrast dominant readings of 'bad' fandom (excessive, transformative, feminine), with dominant readings of 'good' fandom (appreciative, supportive, commercial)," ultimately attempting to "discipline fandom into one particular identity" (p. 75-76). Coulson's fannish affect for Captain America and the fact that moments of fannish feminine excess (such as the aforementioned exchange about watching Rogers sleep) are played for potentially homophobic laughs, can be read as serving a similarly disciplinary function. The Avengers' (2012) writer-director Joss Whedon has a history of such disciplinary fan representations, utilizing the "evil trio" in season six of Buffy the Vampire Slayer to "construct 'acceptable' fan activity [... by building critiques of unruly fans directly into the text" (Johnson, 2007, p. 295). Coulson's representation as a fanboy collector in The Avengers take the inverse approach, and that this fan proxy character is martyred rather than mortified only reaffirms his primary function to model the desired MCU everyfan.

When Coulson, in a moment of ill-advised heroism, is stabbed by Loki, the transmedia franchising logics of the MCU and Coulson's dual roles as transmedia producer and everyfan fuse to create the film's $2^{\text {nd }}$ act turn. Loki, prior to stabbing Coulson, jeers that he has already won, as Coulson's "heroes are scattered" through a combination of in-fighting, mental 
manipulation, and physical dislocation. This comment, clearly intended to cut deeper than Coulson's physical wound, nonetheless reaffirms Coulson's primary narrative function within the transmedia franchise. On his deathbed, Coulson reassures Nick Fury: "It's okay, boss, this was never going to work unless they had something to-_" Coulson dies before finishing his sentence, but the message that his death will be the event to ultimately rouse the Avengers to assemble for the film's climactic battle is implied.

Fury does precisely this, lecturing the two remaining Avengers, Stark and Rogers (each emblematic of the team's ideological and leadership divisions), on the initial impetus behind The Avengers Initiative "to bring together a group of remarkable people to see if they could become something more." Reminding the pair, "Phil Coulson died, still believing in that idea," Fury punctuates this speech by tossing Coulson's still unsigned Captain America trading cards, stained in his own blood, onto the conference table. Though we later learn that Fury bloodied up the cards himself in order to give the superheroes a "push in the right direction" (like any respectable collector, Coulson kept them safely in his locker to preserve their quality), this callback to Coulson as fan collector, and its explicit narratological connection to the superhero collection at the heart of the MCU's franchising logics, is significant.

\section{\#CoulsonLives: Agents of S.H.I.E.L.D and Beyond}

Fittingly, collectible company EFX created replicas of Coulson's Captain America Trading Cards (containing "original" and "bloody" variants). This collectible commemoration of the character speaks to both Coulson's significance within the MCU, but also fans' intense connection to him. A mere three days after The Avengers arrived in theaters, fans had taken to social media, launching the hashtag \#CoulsonLives in an activist effort to bring Coulson back from the dead. Though this fan activism powerfully conveyed how integral Coulson had become to fans' experience of the MCU, it was ultimately franchising logics, rather than fan affect, that resurrected the character. 
Two months after The Avengers (2012) release, the trades announced that writer/director Joss Whedon had inked a three-year deal with Marvel Studios that included the development of a live action television series for ABC (Graser, 2012).S.H.I.E.L.D. (what would ultimately become Agents of S.H.I.E.L.D) was announced three weeks later (Goldberg, 2012). At New York Comic-Con in October 2012, Coulson's rebirth via the television series was confirmed for fans, with Gregg crediting fan activism and the character's fan identity for his transmedia revival: "When he died, the nerds brought him back to life with a hashtag, \#CoulsonLives. The nerds, my people, as a nerd, they have a real connection with Phil Coulson" (Gregg, as cited in Eisenberg, 2014). As its first significant foray into expanding the MCU into other media platforms, Disney unquestionably banked on Coulson's fan appeal, and his established function as the fictive binding agent for the franchise, to bring MCU transmedia fans to television.

A comprehensive analysis of Coulson's characterization on Agents of S.H.I.E.L.D. is unfortunately outside the scope of this particular project. Coulson's elevation to leading man/protagonist is significant, as is his continued diegetic depiction as a binding force (here, as the paternalistic leader of a close-knit collective of agents). Even the series' costume designer was attentive to this shift in status, noting: "In the previous films Coulson has always been a 'company man'. [... The idea was to blend in and not draw attention. Now that Coulson is back after being 'killed' by Loki, we are seeing a subtle change in his wardrobe. [... The inspiration I drew from for him was Daniel Craig from the Bond films" (Kucharski, 2013, para. 9). Paradoxically, as Coulson was narratively and sartorially elevated beyond his "company man" status, thereby affirming his character's place of prominence within the MCU and its fandom, his textual connections and centrality to the transmedia franchise at large evaporated.

Instead of affirming Coulson's transmedia centrality, Agents of S.H.I.E.L.D. has largely remained narratively isolated from the MCU. As Whedon himself has made clear, "As far as I'm concerned in the films, yes [Coulson]'s dead” (as cited in Tilly, 2015, para. 4). If, as Leora Hadas 
(2014) has suggested, Agents of S.H.I.E.L.D.'s connection to the MCU and its authentication as a significant transmedia extension was promoted to fans predominantly through Whedon's presence, then Whedon was also essential in discursively distancing Coulson (and the series by extension) from the MCU's unfolding transmedia fiction. Agents of S.H.I.E.L.D. is occasionally forced into direct conversation with the MCU's textual timeline, most notably when the television series' titular government agency was revealed to be a front for the villainous Hydra and dismantled in Captain America: The Winter Soldier (Feige, Russo, \& Russo, 2014). However, these hyped "crossover episodes" (such as season 1's “Turn, Turn, Turn") have been few and far between and rarely have a lasting diegetic impact, often leaving fans frustrated at the lack of transmedia connectivity. Somewhat ironically, then, the television series routinely undercuts the kind of transmedia consumption that Coulson was designed to model, and that the character's rebirth and centrality to the MCU's expansion into television appeared to valorize. We might ultimately read Coulson's evolution as exposing the false sense of agency that transmedia franchises can generate in their fans, in which the continued, conspicuous consumption of the transmedia franchise is indefinitely sustained by the promise of participation and textual connectivity.

Admittedly, there are myriad legal, logistical, and economic reasons why superheroes from the MCU don't appear on Agents of S.H.I.E.L.D. (Loeb, 2013); as Derek Johnson (2013, pp. 107-151) argues, the industrial realities of worldsharing are markedly more complex than transmedia worldbuilding. Coulson's relative impotence as a transmedia agent on the television series is nonetheless compounded by Marvel's Agents of S.H.I.E.L.D. comics series (Guggenheim \& Peralta, 2016), which routinely features Coulson and his televisual team cavorting with superheroes like Iron Man and Spider-Man (Figure 2). These comics, despite being promoted as "inspired by the hit TV series," explicitly exist outside of the continuity of the MCU, and thus function as a sort of transmedia fan service, cultivating connections with Marvel's comic book continuity in a way that the television series promises, but fails to do so meaningfully, with the MCU. 


\section{Figure 2. Cover of Agents of S.H.I.E.L.D. \#005}

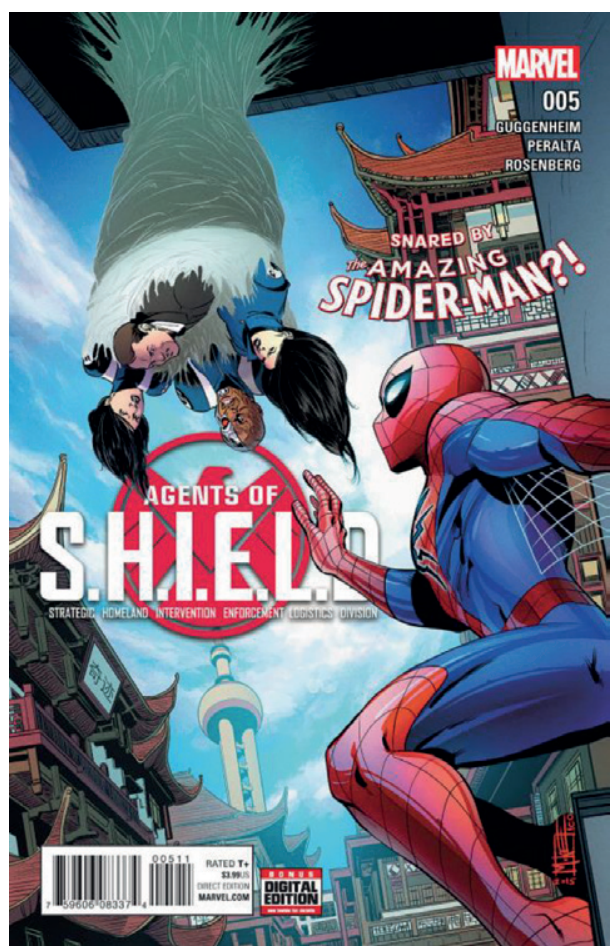

Source: Marvel Comics.

\section{Conclusion: From Transmedia to Transformative Works}

Clearly, longitudinal ethnographic study is necessary to fully understand how audiences make sense of character-oriented transmedia planning broadly, or why Coulson specifically proved to be such a resonant figure for fans of the MCU transmedia franchise. Because pre-existing work on transmedia audiences tends to use the term fan indiscriminately to classify loyal media consumers (Simons, 2014), further qualitative work is also needed on how fans, as a distinct consumer demographic with distinctly gendered modes of media engagement, navigate transmedia franchises. Considering this project's emphasis on character-driven diegetic and paratextual messaging and modeling within transmedia franchises, I will close with a brief consideration of those fans who don't conform to this transmedia franchise everyfan archetype in their reading strategies or participatory practices. 
In their collection Sherlock and Transmedia Fandom, Louisa Ellen Stein and Kristina Busse (2012) suggest that a more expansive definition of transmedia "would suggest that audiences as well as official authors co-construct transmedia narrative, storyworlds, and frames for engagement” (p. 14). As the analysis above suggests, this is precisely the vision of transmedia fan participation that Coulson (and transmedia franchises, by extension) symbolically work to circumvent by valuing a controlled, canonical, and collectible mode of participation. This in no way, however, forecloses fans' drive to produce transformative, or potentially subversive, fan works. Coulson is a popular character within MCU slash pairings, commonly shipped with Clint Barton/Hawkeye and Steve Rogers/Captain America, amongst others. Indeed, an examination of how Coulson has been repeatedly and enthusiastically queered via a range of fannish textual production, would undoubtedly offer a compelling counterpoint to this article's core argument. As one Tumblr fan site devoted to Clint/Coulson shippers notes, fans only needed 47 seconds of the screentime interaction in Thor, a handful of panels from $\mathrm{Fu}$ ry's Big Week (Yost, Pearson \& Ross, 2012) (one of the prequel transmedia comics tied to The Avengers), and one official trading card featuring both characters together, to establish a romantic relationship between the characters and produce thousands of fan texts exploring it ("Fuck Yeah Clint/ Coulson," 2012). Here, we see how forensic fan impulses that characterize transmedia fan culture might be deployed to very different (and potentially industrially undesirable) effect. Regardless of how forcefully the MCU might endeavor to pattern particular modes of fan engagement with their transmedia franchises, fan agency can never be fully contained.

I will accordingly conclude this article with a brief consideration of how fan artists have rendered Coulson's fan identity, suggesting that they representationally nuance and subtly comment on the "desirable" transmedia fandom that the character has come to embody. Because many fans fall outside the paradigm of transmedia franchise fandom, they perhaps take pleasure in wresting Coulson (however briefly or symbolically) away from the MCU's control. Much of this fan art recuperates Coulson's cinematically pathologized representation as a feminized fan. One example of such fan art, by Heidi Black (Figure 3), is representative of these fanworks, 
which simultaneously pay homage to Coulson as a fan collector while foregrounding the affective (and potentially romantic) underpinnings of his Captain America fandom. Here, we see him laden down with merchandise, but Coulson's smile and the heart icon reframes what drives this consumption. Hearts like this one, evoking the ways in which iconic markers and pictorial runes are used in manga to convey characters' interior emotional states (Abbott \& Forceville, 2011), are a staple within fan art representing Coulson as a fan. Hearts ring his head as he is depicted watching Captain America newsreels as a boy, hugging the superhero's iconic shield, gazing at his trading cards, and so on. An array of fan images similarly reposition Coulson as a stereotypical "fangirl": fan art in the aggressively cute Chibi anime aesthetic depicts Coulson singing a parody version of Carly Rae Jepsen's ode to crushes, "Call Me Maybe," to Captain America, and image macros envision Coulson engaging in historically "feminine" fan practices, cross-stitching an image of Captain America.

Figure 3. Fan art depicting Coulson as a fanboy

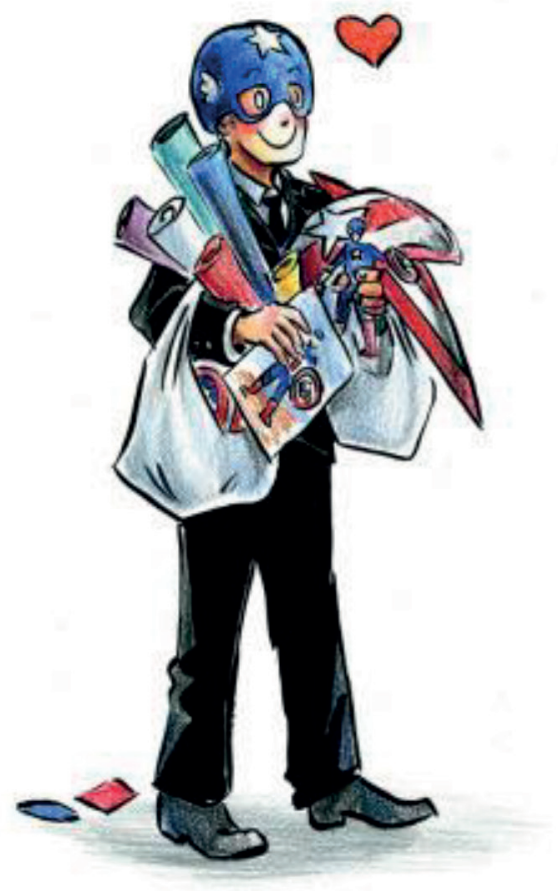

Source: Heidi Black (2012). 
Coulson thus ultimately functions simultaneous as (or occupies a liminal space between) industrial strategy and fannish tactic (de Certeau, 1988, pp. 34-39), modeling transmedia fan engagement and being transformatively remodeled into a more feminized, affective fan presence. Fans' ongoing attachment to the character speaks to his power as a fan proxy. It is important to remember, however, that Coulson has functioned within the MCU not only as a fan proxy, but as a pedagogue. With the transmedia franchise firmly established, one could argue that Coulson has moved from modeling modes of transmedia fan consumption specifically to sanctioned fan engagement more generally. It is notable that one of the transmedia connections to the MCU that Agents of S.H.I.E.L.D. has most actively cultivated is a passing reference/recurring joke in The Avengers regarding Coulson's relationship status with a female cellist. The cellist was later identified as Audrey Nathan (portrayed by Amy Acker) in a first season episode titled "The Only Light in the Darkness," and the television series has since staunchly depicted Coulson in a series of heterosexual relationships. Whether this was an explicit attempt to course correct or speak back to Coulson's feminized fan affect for Captain America and his popularity in slash ships (or the propensity of female fans to queer MCU superheroes more generally) is somewhat beside the point. In addition to examining how media industries attempt to legally or paratextually attempt to facilitate those modes of fan participation that they find financially and promotionally desirable, we also must consider how fan participation is either modeled, contained, or curtailed by the text itself as well as its most powerful agents, its characters.

\section{References}

Abbott, M., \& Forceville, C. (2011). Visual representation of emotion in manga: Loss of control is loss of hands in Azumanga Daioh Volume 4. Language and Literature, 20(2), 91-112.

Arad, A., Feige, K. (Producers), \& Favreau, J. (Director). (2008). Iron Man [Motion picture]. United States: Paramount Pictures. 
Arad, A., Hurd, G. A., Feige, K. (Producers), \& Leterrier, L. (2008). The incredible Hulk [Motion picture]. United States: Universal Pictures.

Black, H. (2012, May 8). Trying out my new caran d'ache colored pencils on some fanboy Coulson [Tumblr post]. Retrieved from http:// heidiblack.tumblr.com/post/22660116209/trying-out-my-newcaran-dache-colored-pencils-on

Booth, P. (2015). Playing fans: Negotiating fandom and media in the digital age. Iowa City, IA: University of Iowa Press.

Busse, K. (2013). Geek hierarchies, boundary policing, and the gendering of the good fan. Participations, 10(1), 73-91.

Connor, J. D. (2012). The biggest independent pictures ever made: Industrial reflexivity today. In C. Lucia, R. Grundmann, \& A. Simon (Eds.), The Wiley-Blackwell history of American film (pp. 517-541). Hoboken: Wiley-Blackwell.

de Certeau, M. (1988). The practice of everyday life. Berkeley, CA: University of California Press.

Eco, U. (1979). The role of the reader: Explorations in the semiotics of texts. Bloomington, IN: Indiana University Press.

Eisenberg, E. (2014). Agent Coulson wouldn't be alive without Twitter. Cinemablend. Retrieved from http://www.cinemablend. com/television/Agent-Coulson-Wouldn-t-Alive-Twitter-67600. html?story_page=1

Evans, E. (2008). Character, audience agency and transmedia drama. Media, Culture \& Society, 30(2), 197-213.

Feige, K. (Producer), \& Branagh, K. (Director). (2011). Thor [Motion picture]. United States: Paramount Pictures. 
Feige, K. (Producer), \& Favreau, J. (Director). (2010). Iron Man 2 [Motion picture]. United States: Paramount Pictures.

Feige, K. (Producer), \& Whedon, J. (Director). (2012). The Avengers [Motion picture]. United States: Walt Disney Studios Motion Pictures.

Ford, S., \& Jenkins, H. (2009). Managing multiplicity in superhero comics. In P. Harrigan \& N. Wardrip-Fruin (Eds.), Third person: Authoring and exploring vast narratives (pp.303-309). Cambridge: MIT Press.

Fuck Yeah Clint/Coulson (2012, June 1). Sure thing, anon! You see... [Tumblr post]. Retrieved from http://fuckyeahclintcoulson.tumblr. com/post/24191111392/we-were-asked-to-make-this-answerfrom-yesterday-a

Geraghty, L. (2014). Cult collectors: Nostalgia, fandom and collecting popular culture. New York, NY: Routledge.

Goldberg, L. (2012, August 28). ABC orders Marvel's 'S.H.I.E.L.D' to pilot from Joss Whedon. The Hollywood Reporter. Retrieved from http://www.hollywoodreporter.com/live-feed/abc-marvel-josswhedon-shield-pilot-365884

Graser, M. (2009, August 31). Disney to buy Marvel for $\$ 4$ billion. Variety. Retrieved from http://variety.com/2009/film/markets-festivals/ disney-to-buy-marvel-for-4-billion-1118007932/

Graser, M. (2012, August 7). Joss Whedon to write, direct 'Avengers' sequel. Variety. Retrieved from http://variety.com/2012/film/news/josswhedon-to-write-direct-avengers-sequel-1118057576/

Gray, J. (2010). Show sold separately: Promos, spoilers, and other media paratexts. New York: New York University Press.

Guggenheim, M. \& Peralta, G. (2016). Agents of S.H.I.E.L.D. New York, NY: Marvel Comics. 
Hadas, L. (2014). Authorship and authenticity in the transmedia brand: The case of Marvel's Agents of S.H.I.E.L.D. Networking Knowledge, 7(1), 7-17.

Harrigan, P., \& Wardrip-Fruin, N. (2009). Third person: Authoring and exploring vast narratives. Cambridge, MA: MIT Press.

Hills, M. (2012). Torchwood's trans-transmedia: Media tie-ins and brand 'fanagement.' Participations, 9(2), 409-428.

Jenkins, H. (1992). Textual poachers: Television fans and participatory culture. New York, NY: Routledge.

Jenkins, H. (2003, January 15). Transmedia storytelling. Technology Review. Retrieved from https://www.technologyreview.com/s/401760/ transmedia-storytelling/

Jenkins, H. (2006). Convergence culture: Where old and new media collide. New York, NY: New York University Press.

Jenkins, H. (2007, March 22). Transmedia storytelling 101 [Blog post]. Retrieved from http://henryjenkins.org/2007/03/transmedia storytelling_101.html

Johnson, D. (2007). Fan-tagonism: Factions, institutions, and constitutive hegemonies of fandom. In J. Gray, C. Sandvoss, \& C. L. Harrington (Eds.), Fandom: Identities and communities in a mediated world, (pp. 285-300). New York, NY: New York University Press.

Johnson, D. (2012). Cinematic destiny: Marvel Studios and the trade stories of industrial convergence. Cinema Journal, 52(1), 1-24.

Johnson, D. (2013). Media franchising: Creative license and collaboration in the culture industries. New York, NY: New York University Press. 
Johnston, J. (Director), \& Feige, K. (Producer). (2011). Captain America: The First Avenger [Motion picture].Uinted States: Paramount Pictures.

Julian, M. (2011, August 2). New Marvel teaser featuring S.H.I.E.L.D.'s Agent Coulson. Comicbookmovie.com. Retrieved from https:// www.comicbookmovie.com/avengers/new-marvel-teaser-featuring-shields-agent-coulson-a43477

Kinder, M. (1991). Playing with power in movies, television, and video games: From Muppet Babies to Teenage Mutant Ninja Turtles. Berkeley, CA: University of California Press.

Kompare, D. (2011). More 'moments of television': Online cult television authorship. In M. Kackman, M. Binfield., M. T. Payne, A. Perlman, \& B. Sebok (Eds.), FlowTV: Television in the age of media convergence, (pp. 95-113). New York, NY: Routledge.

Kucharski, J. (2013, December 19). Agents of S.H.I.E.L.D. Costume Design. Tyranny of Style. Retrieved from http://tyrannyofstyle.com/ agents-of-shield-costume-design

Lee, S., \& Kirby, J. (1965). Strange Tales \#135. New York, NY: Marvel Comics.

Levy, S. (2010). Hackers: Heroes of the computer revolution (25 ${ }^{\text {th }}$ anniversary edition). Sebastapol, CA: O’Reilly Media.

Loeb, J. (Executive Producer). (2013). Agents of S.H.I.E.L.D. [Television series]. Los Angeles, $\mathrm{CA}$ : ABC.

Long, G. (2007). Transmedia storytelling: Business, aesthetics and production at the Jim Henson Company (Unpublished master's thesis). MIT, MA: Cambridge. 
Mittell, J. (2009). Sites of participation: Wiki fandom and the case of Lostpedia. Transformative Works and Cultures, 3. Doi: 10.3983/ twc.2009.0118.

Mittell, J. (2015). Complex TV: The poetics of contemporary television storytelling. New York, NY: New York University Press.

PGA Board of Directors Approves Addition of Transmedia Producer to Guild's Producers Code of Credits. (2010, April 6). Producers Guild of America. Retrieved from http://www.producersguild.org/ news/39637/PGA-Board-of-Directors-Approves-Addition-ofTransmedia-Producer-to-Guilds-Producers-Code-of-Credits.htm

Feige, K. (Producer), Russo, A., \& Russo, J. (Directors). (2014). Captain America: The winter soldier [Motion picture]. United States: Walt Disney Studios Motion Pictures.

Scolari, C. (2009). Transmedia storytelling: Implicit consumers, narrative worlds, and branding in contemporary media production. International Journal of Communication, 3, 586-606.

Scott, S. (2010). The trouble with transmediation: Fandom's negotiation of transmedia storytelling systems. Spectator, 30(1), 30-34.

Scott, S. (2012). Who's steering the mothership?: The role of the fanboy auteur in transmedia storytelling. In A. Delwiche, \& J. Henderson (Eds.), The participatory cultures handbook (pp. 43-52). New York, NY: Routledge.

Scott, S. (2013a). Battlestar Galactica: Fans and ancillary content. In J. Mittell \& E. Thompson (Eds.), How to watch television: Media criticism in practice (pp. 320-329). New York, NY: New York University Press. 
Scott, S. (2013b). Fangirls in refrigerators: The politics of (in)visibility in comic book culture. Transformative Works and Cultures, 13. Doi: 10.3983/twc.2013.0460.

Simons, N. (2014). Audience reception of cross- and transmedia TV drama in the age of convergence. International Journal of Communication, 8, 2220-2239.

Stein, L. E., \& Busse, K. (2012). Introduction: The literary, televisual, and digital adventures of the beloved detective. In L. E. Stein, \& K. Busse, (Eds.), Sherlock and Transmedia Fandom: Essays on the BBC Series (pp. 9-24). Jefferson: McFarland \& Company.

Tankel, J. D. \& Murphy, K. (1998). Collecting comic books: A study of the fan and curatorial consumption. In C. Harris \& A. Alexander (Eds.), Theorizing fandom: Fans, subculture and identity (pp. 5569). Cresskill, NJ: Hampton Press.

Tilly, C. (2015, April 27). Why the Marvel movie guys are annoyed with Joss Whedon. IGN. Retrieved from http://www.ign.com/articles/2015/04/27/why-the-marvel-movie-guys-are-annoyedwith-joss-whedon

Toton, S. (2008, January 17). Cataloging knowledge: Gender, generative fandom, and the Battlestar Wiki [Online forum]. Retrieved from: http://flowtv.org/?p=1060

Yost, C. \& Pearson, E. \& Ross, L. (2012). Fury's Big Week. New York, NY: Marvel Comics. 